\title{
NORMATIWITEIT VERSUS NEUTRALITEIT IN DIE HANDELSWETENSKAPPE
}

\section{Die antitese}

Die sondeval van die mens het ' $n$ tydperk van stryd ontsluit; dit is die stryd tussen die mag van die lig en die mag van die duicternis wat hom telkens in nuwe en meer manifestasies openbaar het. Daarom kon die Collegium Studiosorum Veritas van die Utrechtse Universiteit in die voorwoord tot die bundel voordragte wat by geleentheid van sy $12 \mathrm{e}$ lustrum onder die titel "Geloof en Wetenschap" gehou is, as volg verwys na die openbaring van hierdie stryd op wetenskapsterrein: „Sinds tientallen jaren immers is de verhouding tussen geloof en wetenschap het vraagstuk, waarmee generaties van Christelijke wetenschapsbeoefenaars en studenten hebben geworsteld. Aan dit onderwerp zijn tallose redevoeringen en eindeloze debatten gewijd sedert de natuurwetenschappen in de laatste helft van de vorige eeu zulk een overweldigende vlucht namen. De verbazing, die de mens vervulde toen hij ontdekte welke mogelijkheden er in de natuur verborgen lagen, zwol aan tot een hybris, die God dood verklaarde en de hemel onbewoond".'

Die anvang van hierdie stryd moet egter veel verder terug gevoer word as die helfte van die vorige eeu; in die vroeë Middeleeue het die stryd hom voltrek rondom die tema, geloof vs die wete, terwyl die Christendom deur bemiddeling van St Thomas van Aquinas gepoog het om 'n sintese te bewerkstellig tussen die kerklike leerstellings en die Griekse Wysbegeerte van Aristoteles. Hoewel Aquinas van oortuiging was dat die openbaring deur beide die natuur ( $d$ i die menslike rede), en die bonatuur ( $\mathrm{d}$ i die genade of geloof), nodig was om tot volle openbaring van die waarheid in God te kom, het hy hierdie menslike rede en die menslike geloof as wesentlik van mekaar geskeie aanvaar.

Dat die rede 'n sterker aksent en 'n meer abso'ute stempel sou verkry in die rasionalistiese tydvak sedert die $17 \mathrm{e}$ eeu, val eintlik vanselfsprekend. Hierdie hoogskatting van die menslike rede het nie geskied in dankbare erkenning teenoor God wat die mens sy vermoë tot analitiese denke geskenk het nie, maar was 'n openbaring van sy selfontdekking en die geloof in sy eie menslike vermoëns wat hom in staat kon 
stel om oor die natuur te heers deur bloot van sy aangebore kennis gebruik te maak. So kon Galilei reeds verklaar dat die mens die wetenskap, d i sekere onveranderlike natuurwette, kan gebruik om oor die natuur te heers.

Dit was egter die eksistensialis, Descartes, wat as vader van die scientialisme, die deurbraak gemaak het tot algehele skeiding van menslike geloof en menslike rede met die oortuiging daaraan verbind dat die rede en die wetenskap soewerein en die geloof daaraan ondergeskik is. Die wetenskap, so beweer Descartes, het geen band hoegenaamd met die verlede nie, maar moet eksistensieel afgelei word deur die metode van metodiese twyfel uit self-evidente, klaar en duidelik gekende waarhede. ${ }^{2}$

Hierdie scientialistiese beklemtoning van die wetenskaplike kennis ten koste van die geloof in die geopenbaarde waarhede aangaande God en skepping, het verdere momentum op die lyf geloop deur die evolusionistiese positivisme van Charles Darwin deur sy pragmatiese verklaring van die biotiese afkoms van mens en dier. Hierdie ewolusieleer het eenvoudig geen twyfel gelaat omtrent die ondergeskikte posisie van die geloof in die geopenbaarde waarhede aangaande God teenoor die nugter, saaklik-beredeneerde stellinge van die wetenskap nie.

Wat die verhouding tussen geloof en rede betref van die tyd waarin ons leef, is A Dondeyne in die genoemde lustrumreeks van die Utrechtse Universiteit, van oortuiging dat dit nie meer soseer gaan om 'n stryd tot erkenning tussen Christelike geloof en menslike rede nie, maar dat die nie-Christelike kring die bestaan van die Christelike geloof wel wil erken, maar dat daarby 'n strategie gevolg word van verdagmaking asof die Christelike geloof skadelik en daarom 'n hindernis vir die vrye en onbelemmerde soeke na die wetenskaplike waarheid en beskawingsvooruitgang vorm; ${ }^{3}$ die Christelike normatiwiteit word dus wel erken maar dan ten enemale net buite die wetenskap; geloof in Christus kan dus in die wetenskap geen rol speel nie; die mens moet vry en onbevange van voor-wetenskaplike beïnvloeding die wetenskapsterrein benader - slegs dan kan sy wetenskapsoefening 'n ware objektiewe stempel dra!

Hierdie stryd tussen geloof en die ongeloof, normatiwiteit en neutraliteit in die wetenskapsbeoefening wat hom reeds 
oor vele eeue ononderbroke voortsit, en in die toekoms in intensiteit sal uitbrei, het, met verloop van tyd, vele omskrywings op die lyf geloop soos natuur teenoor genade, geloof teenoor rede, Christendom teenoor die humanisme, dogma teenoor vry ondersoek, normatiwiteit teenoor die neutraliteit, terwyl die Hollandse wysgeer-ekonoom, T P van der Kooy, hierdie onderskeiding op ekonomiese terrein herlei tot die stel van die beginsel teenoor die belang; hy bevind dat in die praktyk die beginsel dikwels as die swakkere, die vlag moet stryk voor die belang. "Het is wel heel mooi er beginselen op na te houden, zo zegt men dan, maar het gezond verstand moet ook een woordje meespreken". ${ }^{5}$

\section{Neutraliteit in die ekonomie (ic handelswetenskappe)}

In terme van die problematiek aan die orde in hierdie lesingreeks, is dit werklik reëel om van 'n neutrale beoefening van die handelswetenskappe uit te gaan? Leen 'n nugter en saaklike wetenskap soos die Ekonomie hom inderdaad vir normatiewe besinning? Is die ekonomie nie maar slegs 'n middel tot 'n doel, 'n instrument ter beheersing van die materiële aspekte van die skepping nie?

Die blote stel van hierdie vrae vorm klinkklare bewys vir 'n neutrale geesteshouding in die beoefening van die handelswetenskappe wat so onopgemerk ingesluip het dat die bestaan daarvan nouliks die Christelike gewete aanklaag as nie in korrelasie met die Christelike belydenis nie. Daarom is dit noodsaaklik om vooraf 'n saaklike weergawe te doen van die neutraliteitsinslag in die moderne positivistiese ekonomie.

Die neutrale ekonomie wat sy oorsprong reeds het in die rasionalistiese en materialistiese denkbee!de van die Renaissance, en grootliks versterk is deur die moderne ontplooiing van die ekonomiese lewe, die wetenskap en die tegniek, sluit in die materialistiese beskouing dat die mens uitsluitlik deur sy eie-belang beweeg word, en deur die maksimalisasie van sy eie-belang, ook die sosiale belang ontwikkel en bevorder. Die primêre dryfvere, volgens die kapitalistiese etiek, is die verkryging van maksimum nut en maksimum wins waartoe kapitaal as die sentrale produksiefaktor, die grootste aandeel het. Die materiële dryfvere van nut (behoeftebevrediging) en wins is die doel, en daaromheen moet alle menslike ekonomie- 
aktiwiteite gebou wees; ekonomie-waardes moet in Rand gemeet word, maar die ekonomie mag hom nie laat betrek omtrent 'n dieper besinning omtrent die waardebegrip of die doele van menslike handelinge nie, want saam met beskouings omtrent roeping, beginsels (norme) en voorwetenskaplike standpuntstellings, vorm dit 'n blote geredekawel wat geen verband met die werklikheid het nie; in die Ekonomie, word geredeneer, moet dit tog om 'n doel gaan, en niks kan meer vanselfsprekend wees dat hierdie doel verband moet hou met die materiële aspekte van die menslike eksistensie nie; dit is deurslaggewend, en die ekonoom moet hom weerhou van die bybring van oorwegings wat hom op 'n syspoor kan laat beland en dus sy saaklike doel uit die oog laat verloor.

Om die saaklike doelstelling van voorsiening van materiële middele vir die menslike bestaan te vind, moet ' $n$ middel gevind word, en hierdie middel tot die doel, is die vakwetenskap, Ekonomie, wat vry moet staan van enige voorwetenskaplike veronderstellings, behalwe 'n floue verwysing na die mens se verantwoordelikheid; wat is egter die betekenis van verantwoordelikheid indien dit nie gepaard gaan met 'n verwysing na die „waarvoor?" en die ,aan wie?" van verantwoordelikheid nie? Van der Kooy is dus van mening dat die Ekonomie vanuit die neutrale standpuntstelling ' $n$ uitsluitlike instrumentele karakter verkry, 'n blote middel tot 'n doel, 'n denkapparaat wat in die verwesenliking van sy doelstellinge geen enkele betekenis het nie behalwe in die uitbouing van die doelmatigheid daarvan om sy doelstellinge meer effektief te kan bereik. Van die Ekonomie word daarom die prerogatief ontneem om ' $n$ standpunt in te neem omtrent die oorsprong en bestemming van die mens, omtrent wie dit primêr in ekonomie-beskouinge behoort te gaan, en wat uiteindelik die aard van sy verantwoordelikheid in die ekonomiese sin behoort te vorm.

Alle ekonomie-aktiwiteite van die mens word bepaal deur die "Invisible hand"-konsepsie van Adam Smith, en daarby moet so weinig moontlik ingemeng word, ook van owerheidsweë: 6 die ekonomiese inkomsteverdeling moet die resultaat wees van 'n spontane proses van die heersende ekonomiese orde, die pryshoogte die resultaat van die werking van die onpersoonlike wet van vraag en aanbod, terwyl die prysgawe van die besinning omtrent die waardebegrip 'n gewaardeerde 
beskeie houding van die beoefenaars van die Ekonomie is, wat juis voortvloei uit 'n besondere hoogskatting van die waardebegrip. In sy atomistiese mensbeskouing wil die neutrale Ekonomie slegs die een aspek van die hele mens, nl sy ekonomie-aktiwiteite, uitlig met 'n absolute negering van al die ander aspekte van sy natuurlike menswees; hy word dus 'n eensydig saamgestelde ,homo-economicus" met geen binding hoegenaamd aan die vele ander aspekte van sy hele menswees nie - 'n blote werkshipotese wat inpas in die Ekonomie as ' $n$ meganistiese middel om 'n materiële doel te bereik. Hiermee verloor die Ekonomie as deelwetenskap egter sy verantwoordelikheid om 'n sinsy van die werklikheid te verklaar en word sy soewereiniteit in eie kring opgelos in 'n „Eigengesetzlichkeit" waardeur die wet van God, waaraan alle dinge binne die geskape werklikheid onderworpe moet wees, verloën word.

Ons het vrede met die feit dat die Ekonomie as vakwetenskap as ' $n$ middel tot ' $n$ doel aanvaar word, maar beskou dit uitermate eensydig dat materiële dryfvere die enigste doel van die Ekonomie kan wees; daar is ook die taak tot die ontdekking van die kennis van die waarheid omtrent die werklikheid en dat hierdie kennis in diens van die mensheid gestel moet word. Die Ekonomie as vakwetenskap veronderstel ook roeping en roeping veronderstel iemand wat roep. So verklaar Van der Kooy "In de ontmoeting der middelen mag de ontmoeting met God en de naaste niet worden vergeten. In de wetenschap der economie mag bij de confrontatie van middelen en doeleinden niet worden stilgestaan".? Daarom ag Van der Kooy die normatiewe bevryding van die neutrale Ekonomie 'n bevryding tot slawerny „waaruit opnieuw bevrijding mogelijk is, namelijk door te luisteren naar een beter beginsel", 8 wat veronderstel die erkenning en aanvaarding van die volledige normesisteem van die wetenskap. Slegs as alle norme erken is is die ekonomie-beslissing ten volle verantwoord; noodwendig alle norme want ,de normen zijn onverbrekelijk aan elkaar verbonden", verklaar Van der Kooy, ,aangezien zij de ene en ondeelbare zin van het leven bepalen. Alleen uit de oorsprong van het leven is de samenhang der normen te verstaan. Alleen de Bijbel ontdekt voor ons het geheim van de oorsprong van het leven en van de eenheid der normen, die God heeft neergelegd in de schepping". 9 
So gaan dit in die handelswetenskappe finaliter ook om God, die Alfa en die Omega, die begin en die einde, altyd die eerste, maar ook altyd die laaste. Wie dit wil ontken stel hom tevrede met minder as die volle waarheid en is daarom wetenskaplik nie suiwer in sy beskouinge nie. So kan instemmend met Bavinck verklaar word: „Christenen nu kunnen geen andere overtuiging hebben, dan dat de waarheid op wetenschappelijk gebied alleen dan te vinden is, wanneer men uitgaat van de belijdenis, dat Christus de weg, de waarheid en het leven is, en dat dus niemand tot den Vader, ook als oorsprong en einddoel aller dingen, komt dan door Hem. Deze belijdenis staat niet tegen de wetenschap over, want schepping en herschepping hebben denzelfden oorsprong". ${ }^{10}$

\section{Terminologiese ondersoek}

Ten einde tot 'n sistematies en logies-verantwoorde insig te geraak omtrent die normatiewe inslag van die handelswetenskappe, en of dit ook moontlik is om dit vanuit 'n suiwer neutrale standpunt te benader, sal 'n strategie van ondersoek gevolg word om die terminologie in die probleemstelling van normatiwiteit teenoor neutraliteit in die handelswetenskappe noukeurig in sy wysgerige samehange te ontleed, om aan die hand van die geopenbaarde gesigspunte, tot enige slotsomme te geraak.

Hierdie benaderingswyse van die probleemstelling sal dan meebring dat, in die lig van die aanvaarding van die ekonomiehandelinge van die mens as behorende tot die wetenskap, vasgestel sal moet word wat wetenskap en wetenskaplike sisteem werklik voorstel, om dan 'n plek vir die handelswetenskappe in die sisteem van die wetenskappe te probeer bepaal. In die wetenskapsoefening gaan dit egter om menslike handelinge, en veral in die handelswetenskappe kry hierdie handelinge ' $n$ besondere konnotasie omdat die neutrale Ekonomie daarop bedag is om alle ekonomie-handelinge te vermaterialiseer; daarom sal gepoog word om veral die ekonomie-handeling in 'n skerp lig te fokus. Maar aangesien dit seker nie moontlik is om menslike handelinge te onttrek aan die mens wat die handeling uitvoer nie, sonder om 'n belangrike deel van die waarheid waarop afgestuur word deur sodanige abstraksie prys te gee nie, kan 'n siening omtrent die mens veral in die 
hoedanigheid van sy absolute onselfgenoegsame en afhanklike aard in sy rol as menswees, nie van die bespreking uitgesluit word nie.

Reeds op grond van die gesigspunte wat openbaar mag word aangaande die ontleding van die wetenskap as 'n verklaringsgrond vir die kosmiese werklikheid wat uit verskeie sinsye saamgestel en radikaal nie tot mekaar herleibaar is nie maar tog universeel saamhang en onties op God, die Skepper en Onderhouer van die skepping, aangewese is, sowel as op grond van die gesigspunte wat geopenbaar mag word aangaande die mens en sy betrokkenheid op God, sal gepoog word om 'n bepaalde perspektief $t o v$ die normatiwiteit of neutraliteit in die handelswetenskappe reeds op hierdie stadium vas te stel. Hiermee sal die moontlikhede om verdere bewyse na vore te haal omtrent die normgebondenheid van die handelswetenskappe egter nog nie uitgeput wees nie. Die sterkste bewysmoontlikheid vir die normatiwiteit van die handelswetenskappe rus waarskynlik in die betekenissamestelling van die begrip normatiwiteit met daarteenoor die samestelling van die begrip, neutraliteit.

Met hierdie verdere lading gesigspunte wat op die betrokke begripsontledings behoort te volg, kan dan oorgegaan word tot die formulering van ' $n$ algemene slotsom met betrekking tot die problematiek onder beskouing.

\section{Wetenskaplike samehang}

4.1. Wat is wetenskap? Ten einde die taak en die plek van die handelswetenskappe te kan bepaal in die sisteem van die wetenskappe, is dit nodig om vooraf 'n ontleding te maak van die presiese betekenis van ' $\mathrm{n}$ wetenskap. $\mathrm{Dr} \mathrm{H}$ Bavinck stel 'n verantwoorde wetenskapsbeskouing slegs verbonde aan die Christelike beskouing omtrent God, mens en kosmos want slegs dit omsluit die volle waarheid; hy stel: „Wetenschap heeft haar maatstaf in de waarheid. Wat waar is, is wetenschappelijk, ook al beweerde de gansche wereld het tegendeel; en wat niet waar is, is onwetenschappelijk, al hielden alle menschen het omgekeerde staande"."1

Ten einde tot 'n volledige wetenskapsopvatting te geraak, stel H G Stoker vier basiese eise daarvoor, ${ }^{12} \mathrm{nl}$ eerstens, ' $\mathrm{n}$ doelbewuste verwerwing van kennis as sodanig deur 'n gerigte 
ondersoek op die „wat", die „hoe” en die „waarom" van die kenbare; tweedens, 'n opsetlike begryp, beskryf, verklaar, verstaan en beoordeling van die kenbare, $\mathrm{maw}$ die ontdekking, insien en teoretiese weergawe van die samehang van die kenbare sodat 'n sisteem blootgelê kan word; derdens, die vasstelling of die bewyse vir die kennis volgens die betrokke norme geldig is, $\mathrm{m}$ a w verifiëring van aannames, waarnemings, ondersoek, beredenering en die resultate waartoe in die wetenskaplike ondersoek geraak is; en vierdens, 'n tegniese beheer van die metodes wat in die verwerwing van kennis gebruik word.

Op grond van hierdie vier kriteria kom Stoker dan tot die gevolgtrekking dat 'n wetenskap beskryf kan word "to be knowledge as such, that is (as much as possible) technically verified and (as much as possible) technically systematised". ${ }^{3}$ Herlei tot die vakwetenskap gee hierdie vier kriteria die volgende slotsom: „Die kennis van 'n deur God geskape en bestierde besondere of spesiale groep van saamhorige gegewens binne die kosmiese totaliteit in hul besondersheid", ${ }^{14}$ wat veronderstel dat hierdie groep van saamhorige gegewens eweneens sover moontlik tegnies geverifieerd en sover moontlik tegnies gesistematiseerd moet geskied.

In die problematiek omtrent die normgebondenheid al dan nie van die handelswetenskappe, is die kwalifikasie ,sover moontlik" beide tov die verifiëring en die sistematisering van kennis om as wetenskaplik erkenning te verkry, betekenisvol. Die "sover moontlik" is 'n formele erkenning dat die versameling en interpretasie van die kennis onvolledig en gebrekkig mag wees, eerstens, vanweë die aard van die kenbare, maar tweedens, vanweë die kreatuurlik onselfgenoegsame, be perkte en afhanklike aard van die ondersoeker, sodat hy altyd sien soos deur 'n spieël in 'n raaisel, maar eendag van aangesig tot aangesig; die ondersoeker, en deur hom die mensheid in die algemeen, is daarop aangewese om nou ten dele, maar eendag ten volle te ken! Nou is dit vir ons huidige probleemstelling so noodsaaklik die feit dat die wetenskaplike as ondersoeker onvolkome, afhanklik en onselfgenoegsaam is, en by hierdie inherente onvolkomenheid wat hom eie is ten beste moet aanpas deur sekere noodsaaklike maar onbewysbare voorwetenskaplike veronderstellings te maak. Wie dit erken (en hoe kan dit ooit weerlê word?), vaar onmiddellik uit die 
dampkring van die neutrale wetenskapsvisie na die normgebondenheid van die wetenskap in 'n erkenning van sekere meta-ekonomiese beginselvrae. Om die openbaring van God in beide sy Woord en die skepping te wil negeer as deel van hierdie meta-ekonomiese beginpunte vir die wetenskapsbeoefening, kan homself nouliks eerlik en volkome neutraal in sy wetenskaplike benadering beskou. 'n Verdere verwysing na Bavinck lig die noodsaaklikheid van openbaringsapriori as volg toe: „Wetenschap als zoodanig is, wijl uit de schepping opkomende, niet Christelijk of onchristelijk... Maar omdat er in de wetenschap, evenals overals elders, zoveel schijn en namaak is, schonk God ons in zijne openbaring een gids en een wegwijzer, die bij de beoefening der wetenschap onze schreden richt en ons voor afdwaling behoedt. Christelijke wetenschap is dus zulk eene wetenschap, die bij het licht dier openbaring alle dingen onderzoekt en ze daarom ziet, gelijk zij waarlijk, in hun wezen zijn".15

\subsection{Die sisteem van wetenskappe}

By die kruisindeling van die wetenskappe onderskei Stoker basiese, toegepaste en tegniese wetenskappe. Wat is nou die handelswetenskappe en watter aandeel het hul in hierdie kategoriale verdeling aangesien hul onderlinge verbondenheid ook vir hul normgebondenheid belangrik en beslissend bchoort te wees.

\subsubsection{Basiese wetenskappe}

By hierdie wetenskappe gaan dit om die vorming van basiese kennis ter wille van die waarheid met die oog op die volbrenging van die roeping tot heerskappy oor die geskape werklikheid. In hierdie kategorie klassifiseer Stoker die Ekonomie, maar die Ekonomie verteenwoordig 'n verskeidenheid vakwetenskappe wat in een of ander verband staan met die ontdekking van kennis omtrent die materiële moontlikhede in die skepping wat sedert die sondeval 'n skaarsheid-karakter verkry het relatief tot die mens se menigvuldige behoeftes. Waar dit dan gaan om kennis ter wille van die waarheid wil dit voorkom asof slegs die Waarde- en prysleer, die geldwese en die Ekonomiese Politiek saam met die Ekonomiese Geskie- 
denis en kennis omtrent die ontwikkeling van Ekonomiese denke in hierdie kategorie 'n plek verdien.

\subsubsection{Toegepaste wetenskappe}

Die mens is op aarde geroepe om verskillende roepings te volbring en in die volbrenging daarvan moet hy gebruik maak van sy gespesialiseerde wetenskaplike kennis soos dit op verskillende terreine van hom nodig geag word. Dit is die taak van die toegepaste wetenskappe om die kennis van die basiese wetenskappe ter beskikking van verskillende toepassingsgebiede te stel.

Op eerste oorweging sou dit wou voorkom asof hierdie terrein uitsluitlik die Bedryfsekonomie omsluit, maar die Bedryfsekonomie betref slegs die beperkte terrein van die bedryf en die handel, wo bemarking en finansiering. Die toepassingsterrein van basiese ekonomiese beginsels kan eweneens uitgebrei word na die staatsfinansies, die beplanning van beide nasionale en internasionale ekonomiese groei deur internasionale goedere- en kapitaalbewegings. Eweneens sou die studie en beheer van konjunktuurverskynsels sowel as die wetenskaplike waarneming en verwerking van die feitelike gegewens van 'n verskeidenheid ekonomie-gegewens wat deur die Statistiek en die Ekonometrie waargeneem word, hier 'n tocpassingsveld kan vind. Waar hierdie toegepaste wetenskappe as deelwetenskappe van die basiese ekonomie-teorie te doen het en almal met die mens te doen het, of as ekonomiese ondersoeker of as subjek van ekonomie-oordeel, het hierdie wetenskappe deel aan die norme waaraan die basiese ekonomie-teorie deel het.

\subsubsection{Tegniese wetenskappe}

Dit dien as middel vir 'n bepaalde doel $\mathrm{nl}$ die toepassing van sekere basiese en toegepaste wetenskaplike kennis aan die praktyk wat op die ekonomie-terrein openbaring vind in die Rekeningkunde, Bedryfsrekeningkunde, die Ouditkunde en die nasionale rekeninge. Indien die vakwetenskaplike beskouing van Stoker waarna tevore verwys is op hierdie wetenskappe van toepassing gemaak word, kan hierdie wetenskappe nouliks nog aanvaar word as wetenskappe omdat die gegewens waarmee gewerk word nie direk deur.God geskep 
is nie maar in verband staan met deur die mens verwerfde feitemateriaal. Dit wil dus voorkom asof die vakwetenskaplike beskouing van Stoker, ten einde hierdie wetenskappe te kan akkommodeer, uitgebrei sal moet word met die addendum, deur die mens verworwe of versamelde kennis. Waar die tegniese wetenskappe dan aan die basiese en toegepaste wetenskappe verbind is as sluitstene met die praktyk, is hul aan dieselfde normatiewe bindinge as die basiese en die toegepaste wetenskappe onderhewig, en kan hul selfs nie met hul tegniese aard prysgegee word aan die mite van die neutraliteit nie.

4.3. Die plek van die handelswetenskappe in die sisteem van wetenskappe

Behalwe dat dit nodig was om die samehang van die verskillende handelswetenskappe onder oë te neem, is dit ewe wenslik om ook die plek te bepaal van die handelswetenskappe in die sisteem van ander wetenskappe. Die feit dat hier van "handels"wetenskappe sprake is in 'n reeks wetenskappe wat verband hou met die ekonomie-handeling van die mens (waarvan die ruilhandeling slegs 'n onderdeel vorm), is waarskynlik te wyte aan die aanname van relatiewe skaarste teenoor nut wat hul in 'n bepaalde mark saamtrek. In alle ekonomie-ontledings word basies met die bestaan van 'n mark rekening gehou, sodat die ruilfunksie nie net tot die terrein van die Bedryfsekonomie beperk kan word nie.

Hoewel die ekonomie-handelinge van die mens 'n aspek van die handelinge van die hele mens verteenwoordig, vorm die handels- of ekonomiese wetenskappe nie 'n onderdeel van die Teologie nie; maar dit staan in verband met die Teologie omdat die mens as homo-economicus dieselfde mens is wat onties betrokke is by die geopenbaarde waarhede aangaande God wat die studieveld van die Teologie uitmaak; daarom kan dit ook van die ekonomie-handelende mens verwag word dat hy as hele mens wat by die openbaring omtrent God betrokke is, in sy ekonomie-handelinge ook die eer van God sal soek en sal meewerk tot die koms van Sy Koninkryk. Dit is die roeping van die mens om met die kennis aangaande God en die openbaring van Sy wil in Sy gebooie rekening te hou in sy ekonomie-handelinge. 
Net so vorm die handelswetenskappe geen onderdeel van die Wysbegeerte nie deurdat die Ekonomie slegs die aard en samehang van die ekonomie-verskynsels en handelinge tot veld van ondersoek het, maar tog 'n verhouding met die Wysbegeerte handhaaf omdat die ekonomie-verskynsels deel uitmaak van die kosmies kleine en die kosmies grote wat weer die veld van ondersoek van die Wysbegeerte vorm.

Die Ekonomie ondersoek, wat Stoker noem, 'n selektiefrelevante deel van die kosmiese werklikheid, en vorm daarom 'n deel- of vakwetenskap. Maar in die kategorie vakwetenskappe het dit weer geen deel aan die natuur- en die godsdienswetenskappe nie, dog synde 'n produk van die mens moet dit as 'n kultuurwetenskap erken word waarin die menslike handelinge 'n belangrike plek vervul en dus onmoontlik kan funksioneer in 'n leë normlose ruimte.

\section{Die mens en die menslike handeling}

\subsection{Wie en wat is die mens in die algemeen?}

Elke vakwetenskap het met die mens te doen en moet daarom ' $n$ bepaalde mensbeskouing handhaaf. Aangesien elke vakwetenskap egter dieselfde mens in sy ondersoek betrek, is dit begryplik dat die afsonderlike wetenskappe nie afsonderlik van mekaar ondersoek kan word nie, maar, volgens Stoker, mekaar moet aanvul en bevrug. ${ }^{16}$ Daar moet dus iets gemecnskapliks aanwesig wees in die mensbeskouing soos deur die afsonderlike vakwetenskappe aanvaar en hierdie gemeenskaplike faktor kan nie bloot in die mens se fisiese bestaan saamgetrek wees nie. Die wesentlike aspek van die mens vir alle vakwetenskappe is die feit van die mens se bee'dverbondenheid met God, sy betrokkenheid op God. Om hierdie openbaring aangaande die wese van die mens te misken beteken 'n prinsipiële ander siening van die mens wat noodwendig die wetenskaplike in al sy probleemstellings afleidings en slotsomme fundamenteel moet beïnvloed. So kan Stoker tereg vra: „Wie die verhouding van die mens tot God prinsipieel buite rekening laat, sy verhouding tot God van hom abstraheer, die mens eksklusief kosmies wil verstaan en hom in dié sin verselfstandig, vorm hy nie 'n gereduscerde beeld van die mens waardeur hy in fundamentele en ,wesentlike' sin die mens as méns uit sig verloor en 'n mensbeskouing 
vorm wat per slot van rekening absurd is nie?" 17

Hoewel die mens in sy beeldskap met God in 'n ooreenstemmingsverhouding tot God verkeer, mag die mens nie teenoor God verselfstandig word nie; ten spyte van sy beeldskap met God bly die mens nog fundamenteel onselfgenoegsaam teenoor die absolute selfgenoegsaamheid van God. Die mens bly fundamenteel wetsgebonde terwyl God aan geen Wet gebonde is nie. God bly fundamenteel Skepper en Instandhouer van die skepping, terwyl die mens fundamenteel skepsel en afhanklike bly. God skep absoluut, die mens slegs kreatuurlik; God ken absoluut, die mens slegs kreatuurlik; God is die Skepper uit niks, die mens slegs uit wat reeds tot stand gebring is; God bestier absoluut, die mens bestier slegs die kreatuurlike gegewene. Teen hierdie agtergrond is die mens se beeldverbondenheid met God 'n egter analogie, 'n ooreenstemmingsverhouding, 'n betrokkenheid maar geen verselfstandiging nie.

'n Aspek van ons mensbeskouing wat nie uit die oog verloor mag word nie omdat dit vir die huidige problematiek besondere betekenis het, is die feit dat die mens telkens as hele mens fungeer. So staan die handelsaktiwiteite van die mens i v m die mens maar hy is nie net louter ekonomie-handelende wese nie. J Waterink som dit so op: „Man cannot divide himself into various provinces. He can at most accent a particular side of his being, but even in his scholarly work he continues to love, he continues to believe, he continues to hope. If it were otherwise, he would have to tear his inner man to pieces, and such is, in the case of the normal man, even psychologically, completely impossible".18

\subsection{Die betekenis van die beeldskap Gods vir die onver-} selfstandige Homo Economicus

Die beeldverbondenheid van die mens met God bring mee dat 'n bepaalde faset van die beeld van God telkens in een van die afsonderlike vakwetenskappe afgestraal word; dit bring inderdaad die "verbondenheid" van die mens met die beeld van God wat die mens maak tot 'n volkome "God se mens". omdat Hy hom nie slegs geskep het en onderhou nie, maar hom ook kragtens Sy beeldskap aan Hom verbind.

Die vraag is nou: wat is die bepaalde faset van die beeld 
van God wat op die mens in sy ekonomie-handelinge, $d$ w s die onverselfstandigde homo-economicus, betrekking het? Anders gestel: wat is die aandeel van die homo-economicus aan die beeldskap van God? Of nog anders: wat is die unieke betekenis van die beeldskap van God vir die mens in sy handelinge tot ontberging van die moontlikhede van die skepping in die voorsiening van die mensheid se menigvuldige behoeftes wat sedert die sondeval konstant die voorsieningsmoontlikhede oorskry?

In die besinning omtrent hierdie vraag word van die mens as homo-economicus uitgegaan, $\mathrm{d}$ ws nie die abstrakte wese van die $18 \mathrm{e}$ eeuse klassieke Ekonomie wat deur geen ander motief as die sug na rykdom en materiële welvaart gelei word nie, ${ }^{19}$ maar die natuurlike, hele mens, wat kan liefhê en haat, hoop en wanhoop, glo en twyfel; by die homo-economicus word die fokus slegs ingestel op een sy van sy hele menswees en dit is sy ekonomie-handeling: die selektief-relevante betrokkenheid van die mens by sy ekonomie-taak en -handelinge word slegs voorop gestel. Nie slegs bly die bee'dskap Gods integraal aan hom verbonde waar hy as ekonomie-handelende wese optree nie, maar dit bepaal en kwalifiseer ook in belangrike mate hierdie handelinge van hom. Hierdie beeldskap met God kan nie willekeurig of net op sekere geleenthede vertoon word nie, maar hy dra dit as hele mens en moet dit in al sy lewensuitinge openbaar.

Indien nou tot tiperende van die ekonomie-handeling aanvaar word die ontberging en ontginning van moontlikhede in die skepping tot voorsiening van dienste en goedere wat vir die mens nuttig kan wees vir die bevrediging van sy behoeftes wat sedert die sondeval sy skaars middele oorheers, wil Stoker hierdie „goedere-verskaffende voorsorg"-funksie van die Ekonomie herlei tot die vergestalting van die mens se beeldskap met God..$^{20}$ Hieromtrent vra Stoker dan retories: „Sou (hierdie) menslike voorsien-igheid nie die faset van die menslike beeldskap van God as die Voorsienige by die ekonoom wees nie ...? Sou die vakwetenskap, ,Ekonomie' nie in fundamentele sin met hierdie faset van die menslike beeld van God rekening behoort te hou nie?" ${ }^{21}$ Die implikasie is duidelik dat die goddelike voorsienigheid 'n weerspieëling vind in die menslike voor ienigheid deur sy goedere-verskaffende voorsorgfunksie soos uit sy ekonomie-handelinge en beslissinge aan die lig tree. 
6. Die normgebondenheid van die handelswetenskappe in die lig van die wetenskapsbeskouing en die mens se beeldver. bondenheid met God

In beide die wetenskapsbeskouing wat hiervoor aan die orde gestel was sowel as in die ekonomie-handeling tree die mens duidelik op die voorgrond met bepaalde norme wat sy handelinge rig en bepaal. Hierna verwys Brillenburg Wurth in die volgende: „Zonder de mens laat zich de economie niet denken - dan kan het niet anders, of wij bevinden ons in de normatieve sfeer, d $\mathrm{z} z$ de sfeer, waar bepaalde normen gelden, en is dus de economie een normatieve wetenschap, $\mathrm{d} \mathbf{w} \mathrm{z}$ een wetenschap, die, behalve dat ze heeft te verklaren, hoe de dingen toegaan, ook voor te schrijven heeft, hoe wij als mensen behoren te handelen of althans ons menselijk handelen heeft te beoordelen".22

Waterink vind die mens se religieuse gebondenheid 'n seker wegwyser by al sy handelinge, in 'n sterker mate sy aktiwiteite tot wetenskapbeoefening. Hy verwys hierna as hy verklaar: „Every scholar, in beginning his work, comes to his discipline and to the facts with a particular pre-scientific attitude and view of life. He comes to his work just as he is... Just because man is endowed with reason and understanding, because he is given to function as a prophet and to enter understandingly into things, he needs a starting point, a point of view, from which to approach life in his thought, his feeling and his action. It is my conviction that this is directly related to the fact that man is religious". ${ }^{23}$

Dit is reeds bekende feit dat die mens se geloofsoortuiging sy denke afstempel: die geloof aan verabsoluteerde vryheid skep by hom 'n liberalistiese lewenspatroon; die geloof aan die absoluutheid van die staat skep by hom die sosialisme; die geloof aan die absoluutheid van die volk, skep die nasionaal-sosialisme; die geloof aan die verabsoluteerde reg van die enkeling, skep by hom die individualisme; net so deur die geloof in die God van die voorsienigheid, $\mathrm{nl}$ dat $\mathrm{Hy}$ die oorsprong is van alles wat ontstaan het, en dat alles wat ontstaan het weer sy bestemming in Hom sal vind, dra sy wetenskap die stempel van die Calvinisme - neutrale wetenskap is nêrens te vind nie! Selfs die mees eksakte wetenskap, soos die Wiskunde, kan sonder 'n aksiomastelsel nie klaarkom nie. 
Om die man van wetenskap die steun te ontsê van die wêreldbeskouing wat hy in sy daaglikse lewe handhaaf, ag Van der Kooy nie net onbarmhartig nie maar verteenwoordig vir hom 'n uiters gewigtige aangeleentheid: „Wetenschap die eindigt in een ,lege ruimte' is op de lange duur onbestaanbaar. Misschien kan men in de natuurwetenschap nog iets langer met dit procedé uitkomen dan in de cultuurwetenschap. Maar voor laastgenoemde, voor de wetenschap van het menselijk handelen, is het vacuum geen geschikte atmosfeer. Vandaar dan ook dat de cultuurwetenschap altijd de neiging heeft om te gaan theologiseren". ${ }^{24}$

Omdat dieselfde mens wat betrokke is by die openbaring van God in Sy Woord en in Sy wet, ook die mens is wat geroepe is om ekonomies-handelend te fungeer, het die Teologie ' $n$ aandeel in die vaslegging van die normesisteem wat in die Ekonomie behoort te geld. Die religieuse ingesteldheid van die mens, in terme van Dooyeweerd, 'n gegrepenheid in die hart van die mens omtrent die openbaring aangaande God, kondisioneer sy wetenskaplike denke voordat daarmee begin is.

\section{Normatiwiteit}

Sover kon belangrike feite aan die lig gebring word omtrent die normgebondenheid van die handelswetenskappe, inteendeel, argumente ten behoewe van 'n neutraliteitsvisie kon selfs per implikasie nie vasgestel word nie. Tog is dit noodsaaklik om ietwat dieper te delf vir verdere argumente waarom die positivistiese benadering tot die handelswetenskappe nie erken kan word nie. Gepoog sal word om die verdere argumente tot wetenskaplike normgebondenheid na vore te haal uit die begrippe self, nl normatief of neutraal!

\subsection{Wat is normatief?}

Die norm in die menslike lewe betref die wyse hoedanig die mens as toerekenbare, verantwoordelike wese behoort te handel beide wat sy aktiwiteite ( $\mathrm{d}$ i sintuiglik waarneembare handelinge), en aktes ( $\mathrm{d}$ i nie-sintuiglik maar introspektief waarneembare handelinge, soos denke, waardering, ens), betref.

$\mathrm{Na}$ hierdie „behoort te doen" van die toerekenbare en verantwoordelike mens, verwys Stoker as die "deontiek", di 
die behorenseis van die handeling. Dit gaan dus vir hom in die deontiek of norm om: "What ought man to do and how ought he to do it?" eerstens, as individu, tweedens, as lid van 'n groep of gemeenskap, derdens, as 'n groep of gemeenskap, en vierdens, as mensheid, ${ }^{25}$ terwyl alle behorenseise waaraan die mens as toerekenbare, verantwoordelike wese in sy ganse lewe moet voldoen, saamgevat is in die wetenskap. Deontologie.

In die konteks van die behorenseis wat geld by die menslike handeling in sy beoefening van die wetenskap, is veral die toerekenbaarheid en verantwoordelikheid van die mens belangrik. As toerekenbare wese kan van hom verwag word dat hy hom sal verantwoord omtrent die vrae: „Wat behoort?” en "hoe behoort?" my handeling as wetenskaplike ondersoeker te wees; as wetenskaplike ondersoeker behoort die praktiese vormgewing aan hierdie vrae ook wetenskaplik verantwoord te wees. Dan kan uit hierdie redenasie al dadelik die gevolgtrekking gemaak word dat alle wetenskaplike ondersoek, ten einde wetenskaplik te wees, normgebonde moet wees omdat wetenskaplike ondersoek aan die ondersoeker die eis tot verantwoorde optrede in ooreenstemming met sy toerekenbaarheid stel.

\subsection{Deontieke samehang}

Menslike optrede word deur 'n aantal kategorieë van norme bepaal, nl

\subsubsection{Ontiese norme}

Di kragtens sy skepping deur God in die menswees van die mens bestem, soos o a die vorming van kultuur deur die moontlikhede wat beide in die mens en in die natuur geleë is om in harmonie ontwikkel te word. Daarom is beide die mens en die skepping deonties (normatief) gelade. Hierdie norme stel aan die mens sy taak en in universele sin ook sy roeping ${ }^{26}$ sodat die ekonomiese ontwikkeling van die skepping tot die ontiese norm van die menslike handeling behoort; daarom kan die Ekonomie as vakwetenskap wat aan die mens optredes voorhou tot doelmatige uitvoering van hierdie roeping tot beheersing van die skepping, onmoont.ik anders as deonties (normatief) gebonde te wees. Sou die mens sy ontiese 
taak negeer sou die eis van verantwoordelikheid teenoor Hom wat die taak opgelê het nie langer geld nie.

\subsubsection{Gepositiveerde norme}

D i norme wat deur die mens op grond van eie insigte geformuleer is en as norme neergelê is, bv die maak van wette, regulasies, verordeninge vir die staatkundige gemeenskap, universiteit, vereniging, ens, of die neerlê van reëls vir die maatskaplike omgang, handel, ens.

\subsubsection{Intrinsieke norme}

D i norme wat integraal aan ' $n$ bepaalde wyse van optrede verbonde is, bv die eis van doelmatigheid (rasionaliteit) bv die ekonomie-handeling - die "behoort doelmatig te wees" bepaal hierdie intrinsieke ekonomie norm; sou dit angedui kan word as 'n blote strewe na ekonomiese rasionaliteit sonder dat dit as 'n noodwendigheid geld, het ons te doen met 'n historiese feit; aan die ander kant, indien die mens nie 'n keuse het in sy rasionele optrede nie, het ons 'n natuur-wetmatigheid. Indien ons dan wil erken dat die ekonomie-handeling rasioneel behoort te wees, soos wat die geykte uitgangspunt in alle ekonomie-teorie altyd is, het ons ook outomaties erken dat die handelswetenskappe normatief en wel intrinsiek normatief gebonde is, en is 'n neutraliteitsvisie daaromtrent onmoontlik.

\subsubsection{Transendente norme}

D i norme wat elkeen 'n nie-herleibare kant van die werklikheid verteenwoordig, maar tog ten spyte van die radikale besondersheid van elke kant, ook universeel saamhang. Omdat die Ekonomie 'n binne-kosmiese verskynsel verklaar en deel het aan die totale werklikheid, kan dit eweneens nie van die transendente norme uitgesluit word nie. Hierdie norme sluit in die juridiese, religieuse, etiese, logiese, ens as elkeen 'n kant van die werklikheid, maar omdat nie een 'n volle kant van die werklikheid omvat nie, is dit ook onmoontlik om enigeen daarvan te verabsoluteer in die vorm van logisisme, liberalisme, etisisme, ens. 
Hierdie erkenning van die transendente norme op die gebied van die Ekonomie, doen finalitêr weg met enige moontlikheid tot 'n neutrale benadering van die Ekonomie as vakwetenskap. Daarom is selfs die sgn neutrale Ekonomie nie neutraal nie omdat dit staan op die standpunt van die Ekonomisme - soos Bavinck dit stel, selfs die skeptikus bly 'n propagandis vir die dogma van die twyfel!27

As hierdeur vir die soveelste maal bewys gelewer is dat die religieuse as 'n transendente norm vir die handelswetenskappe noodwendig moet geld, sê dit aan die handelswetenskappe dat God die enigste Abso'ute is, die Al- en Selfgenoegsame oorsprong van alle dinge, die eerste en finale grond van alle dinge, uit Wie, deur Wie en tot Wie alle dinge is. Dit sê aan die mens van die handelswetenskappe nie slegs dat God absoluut is nie, maar dat hyself onvolkome is in homself, in sy rede, sy waarneming, sy aard, sy wetenskap - sy hele bestaan en wetenskap kan s'egs bcoefen word by die grasie van God!

\subsection{Die kontekstuele betekenismoment as bewysgrond vir} die wetenskaplike normgebondenheid

Die norme waarvan hierbo 'n uiteensetting gegee is, het betrekking met verskillende grade van aksentuering op alle menslike optredes waar ook al; omdat die mens as homo economicus deel is van die skepping, volg outomaties dat die Ekonomie wat sy ekonomie-handelinge moet ondersoek en verklaar aan al hierdie norme onderhewig moet wees. Daarom is die Ekonomie nie net aan die gepositiveerde en intrinsieke norme van menslike optrede gebonde nie, maar ook aan die ontiese en die transendente norme. Hierby ge'd die feit dat kosmiese verskynsels eers hul werklike betekenis verkry binne die konteks van sy omringende omstandighede; hoe digter aan die omringende omstandighede beweeg word, hoe duideliker word die beeld van die bepaalde verskynsel, wat beteken dat die verskynsel nie van sy kontekstuele opset losgemaak mag word nie, maar steeds digter daaraan beoordeel moet word vir 'n suiwer waarneming. So geld dit ook vir die handelswetenskappe wat steeds nader aan die kosmiese werklikheid wat dit moet verk'aar, beoordeel moet word, en hoe digter aan die kosmiese werklikheid, hoe sterker raak sy betrokken- 
heid by die normesisteem waarna in verskillende kategorieë hiervoor gewys is.

Die kultuurtaak aan die mens tot beheersing en bewerking van die skepping is ' $n$ ontiese norm waaraan die Ekonomie as vakwetenskap wat juis gefokus is op die vasstelling en ontginning van die materiële dinge in die skepping, 'n ruim aandeel het. In die nalewing van die spreuk: „wie nie werk nie sal nie eet nie" word die pogings tot voorsiening in die mens se materiële bestaan, juis 'n erkenning tot sy ontiese normgebondenheid. Maar die Ekonomie het ook 'n aandeel aan die gepositiveerde normestelsel omdat geordenheid $t o v$ materiële besit en ' $\mathrm{n}$ waarborg to $\mathrm{v}$ onbevooroordeelde regshandhawing noodsaaklike voorvereistes vir die werking van 'n ekonomiese stelsel vorm.

Reeds is verwysing gedoen na die intrinsieke normgebondenheid van die Ekonomie, maar hier dien daarop gewys te word dat die intrinsieke norm by die Ekonomie noue verband handhaaf met die transendente normgebondenheid van die Ekonomie omdat die ekonomie-norm uitgaan van 'n bepaalde maksimum wins of behoeftebevrediging. ${ }^{28}$ Die erkenning van sodanige maksimum moet noodwendig onvermydelik wees anders hou dit nie verband met die ekonomies rasionele mens wat daardeur juis getipeer moet word nie - die ekonomies rasionele mens sou naamlik streef na ad infinitum uitbreiding van sy nut- of winsposisie (indien dit moontlik sou wees), en nie na 'n bepaalde maksimum nie. Nou volg die vraag omtrent Wie bepaal die maksimum van die menslike nut- of winsvoorsiening? want hierdie maksimum is duidelik ook afhanklik van die wasdom wat van Bo kom: Hy gee die sonskyn op die regte tyd, laat reën op die regte tyd, gee die mineralestowwe in die aardkors op die plek en die diepte wat Hy bepaal - alles faktore wat die omvang van die maksimum wins direk beïnvloed! Wie hierdie vrae wil beantwoord kom op die transendente kategorie van ons normesisteem terég.

\section{Neutraliteit}

Nog 'n terrein vir die blootlê van argumente vir die normgebondenheid van die handelswetenskappe bied hom aan in die ontleding van die begrip neutraliteit (objektiwiteit), wat dikwels entoesiasties verkondig word deur sommige beoefenaars van die wetenskap. 
Neutraliteit (objektiwiteit) by die beoefening van die wetenskap vereis dat die beoefenaar van die wetenskap $X, Y$ en $Z$ as behorenseise by die beoefening van die wetenskap nie mag kies nie, sodat $X, Y$ en $Z$ geheel uit die gesigsveld van die wetenskap moet verdwyn. Konkreet gestel, alle deontieke eise wat betrekking het op God, die mens en die kosmos moet uit die wetenskapsvisie negeer word; die voorwetenskaplike veronderstellings omtrent die bestaan van die mens en die skepping moet negeer word, word geredeneer; alle prinsipes en prinsipiële verskille moet laat vaar word, word daarby gevoeg. In die Ekonomie word dan uitgekom by, soos aan die begin van hierdie betoog gestel, 'n blote denkkonstellasie wat 'n bepaalde materiële doel so doelmatig moontlik moet realiseer om dan weggesit te word totdat dit weer vir dieselfde doel later benodig mag word. Dit is die instrumentele Ekonomie wat gebou is om 'n metodologiese beginselloosheid ${ }^{29}$ wat, ten spyte van die wegredeneer van alle voorwetenskaplike veronderstellinge, tog in die antinomie gevange sit dat hul veronderstel dat die ander aspekte as die ekonomiese en die metaekonomiese geen invloed op die mens uitoefen waar hy as louter ekonomie-wese beslissinge neem wat uitsluitlik op sy ekonomie-bestaan betrekking het. Hul is onwetenskaplik genoeg, bereid om die mens as losstaande atome saam te bundel binne sy uiterlike omhulsel. So word hy telkens gesien as homo economicus, homo socius, homo medicus, homo historicus, ens, maar nooit as al hierdie fasette tegelykertyd nie. So het die kontekstuele opset van die mens vir die vrye of neutrale Ekonomie geen enkele betekenis nie - so word die beeld van God in die mens verduister!

Om niks te doen te hê nie, is die credo van die neutraliteit!

Kan dit werklik so wees?

Indien dit so sou kon wees moet alle norme noodwendig uitgesluit word - A-normatiwiteit dus; maar A-normatiwiteit is finaal uitgesluit omdat die Ekonomie met die mens te doen het en die menslike handeling altyd normatief gelade moet wees!

\section{Die normatiwiteit erken}

Dit is die slotsom waartoe alle ontledings en argumente in hierdie betoog heenwys! 
Soos 'n glimstreep in die nag telkens opnuut voor die ligstrale van 'n motor die reisiger herinner aan die weg wat hy moet volg en die gevare waaraan hy andersins blootgestel mag wees, so het ons telkens in die lig van die ontledings in hierdie betoog die glimskyf van die norm moes ontwaar, sodat ons eindelik tot die gevolgtrekkings moes geraak: dit is oral! Dit was aanwesig die hele afstand wat ons gereis het.

Dit het geen onbelangrike rol vervul in ons konsep van wetenskap, in ons mensopvatting as beelddraer van God, in ons bepaling van die deontieke samestelling van die werklikheid, in die kontekstuele verband waarin ons gevind het die mens handel en bestaan, in die onvermydelike apriori by wetenskaplike ontleding - selfs in die beskouing omtrent die konsep van neutraliteit! Om dus die normatiwiteit van die handelswetenskappe te wil verban of te negeer, is sinloos en dwaas en doen af aan die wetenskaplikheid van die ondersoeker wat dit wil beweer.

En in die erkenning van die normatiwiteit van die handelswetenskappe lê 'n fenomenale uitdaging opgesluit, veral vir die beoefenaars daarvan aan die Christelike universiteit waar hierdie normatiwiteitserkenning eintlik sy beslag moet kry - eers dan word die belydenis en die lewenspraktyk met mekaar in ooreenstemming gebring; eers dan word die volle wetenskap geken en beoefen en meegedeel aan diegene wat ons geroep is om daarin te vorm. Daarby verruim en vergemaklik dit ons taak in die beoefening van die wetenskap. Soos 'n skip op 'n anker en kompas aangewese, het die mens sedelike riglyne nodig wat sy ganse lewe moet rig en bestier, ook sy denke aangaande sy ekonomie-handelinge. Hierdie sedelike riglyne, ons waardesisteem of deontieke bepaaldheid van ons handelinge, is die beginsel wat ons lewensuitinge sinvol maak; Van de Kooy vat dit as volg saam: „Het beginsel helpt ons bij het ordenen der verschijnselen, in onze wereldbeschouwing. Het geeft ons vertrouwen bij de opbouw van ons gedragspatroon, van onze lewensstijl. Het steun ons bij de selectie van wat aan de schat van onze traditie moet worden toegevoegd, en wat daarvoor geen waarde heeft, met het oog op de toekomst. Het schenkt ons rust wanneer wij opeens met schrik gewaar worden dat wij uit gewoonte handelen. Maar het sust ons geweten niet in slaap. Het houdt ons wakker om ons gehele levensproject, met alle gewoonten en tradities en over- 
tuigingen die daarin zijn verwerkt, met alle technieken die wij ons hebben aangewend telkens weer opnieuw te toetsen en te louteren in het vuur van de principiële, normatieve richtlijnen, dat uit de grondslag van ons leven oplaait. De spanning wordt niet uit het leven weggenomen, maar zij wordt voor mensen dragelijk. Want de spanning der beginselloosheid, die alleen maar van feiten en hypothesen wil weten, is zinloos en moet leiden tot moedeloosheid. Maar de spanning van het beginsel wordt een vreugdevolle taak. $\mathrm{Zij}$ draagt uit tot inspanning en ontspanning beide. Zij bevrijdt!" 30

\section{W J Venter $\mathrm{PU}$ vir $\mathrm{CHO}$}

1 Collegium Studiosorum Veritas, Utrechtse Universiteit, Geloof en Wetenschap, Voorwoord

2 Spier, J M: Van Thales tot Sartre, 128

3 Dondeyne, A: Dogma en vrip onderzoek, Geloof en Wetenschap, op cit, 53

4 Van der Kooy, T P: Tussen beginsel en belang, 5

5 Idem

6 Adam Smith as grondlegger van die liberalisme, glo dat die beste regering dié is wat die minste regeer; volgens $P$ C Newman se aanhaling in The Development of Economic Thought, is Smith van oordeel: „Every man, as long as he does not violate the laws of justice, is left perfectly free to pursue his own interest his own way, and to bring both his industry and capital into competition with those of any other man, or order of men. The sovereign is completely discharged from a duty, in the attempting to perform which he must always be exposed to innumerable delusion and for the proper performance of which no human wisdom or knowledge could ever be sufficient" 53-54)

7 Van der Kooy, T P op cit, 118

8 Idem

9 Van der Kooy, T P: Op het grensgebied van Economie en Religie, 34

10 Bavinck, H: Christelijke Wetenschap, 121

11 Idem

12 Stoker, H G: Outlines of a Deontology of Scientific Method, Philosophy and Christianity, 60; ook in Beginsels en metodes in die Wetenskap 134, ev

13 Stoker, H G: Philosophy and Christianity, op cit, 60 en Beginsels en metodes in die wetenskap, op cit, 136

14 Stoker, H G: Beginsels en metodes in die wetenskap, op cit, 242

15 Bavinck, H: op cit, 121
} 
16 Stoker, H G: Die betekenis van die mens as beeld van God vir die Wysgerige Antropologie, Oorsprong en Rigting, Band I, 83

17 Ibid, 96-97

18 Waterink, J: On the Scholarly Habitus, 18

19 Hennipman, P: Economisch motief en Economisch principe, 141; Hennipman onderskei verskillende betekenis waarin die begrip gebruik word

20 Stoker, H G: Oorsprong en Rigting, Band I, op cit, 106-107

21 Ibid, 107

22 Brillenburg Wurth, G: Het Christelijk Leven in de Maatschappij, 25

23 Waterink, J: op cit, 19-20; gelykluidend verklaar Van der Kooy in $O p$ het Grensgebied van Economie en Religie, 31: "De normen, die het menselijk beslissen en handelen besturen, zijn van goddelijke oorsprong, want zij vertolken zijn Wet voor de onderscheidene aspecten van het leven. Het niet gehoorzamen aan deze normen doet het leven in stukken uiteenvallen en de zin er van verloren gaan"

24 Van der Kooy, T P: Tussen beginsel en belang, 108-109

25 Stoker, H G: Philosophy and Christianity, op cit, 57

26 Ibid, 58

27 Bavinck, H: op cit, 116

28 Van der Kooy omskryf sy siening van die ekonomie-norm ,als goddelijk opdracht aan de mens tot doelmatig beheer van de aardse goederen", en verwys na die doelmatigheidstrewe as volg: „Het doelmatig streven is een maximum streven; het houdt in het bereiken van een zo groot mogelijk behoeftenbevrediging met gegeven schaarse en alternatief bruikbare middelen; ... het doelmatigheidsondersoek kan... niet worden losgemaakt van het normenonderzoek"; sien Over Economie en Humaniteit, 186, 187 en 190

29 Van der Kooy, T P: Tussen beginsel en belang, op cit, 138

30 Ibid, 128-129 